\title{
PUBLIC POWER AND ATOMIC POWER DEVELOPMENT
}

\author{
Herbert S. Marks*
}

I

A jumble of questions of law, politics, public opinion, economics, and ideology make the subject of public power a rich and confused field of debate. This paper is not concerned with the merits of that debate; it is concerned rather with a lawyer's appraisal of the Atomic Energy Act of 1954 as that law relates to public-power issues. In making such an analysis, it is first necessary to describe the position which public and private power now occupy in the economic system, entirely apart from atomic energy. Next, it is important to know the part which federal law and policy have played in producing these conditions. The relation between federal power policy of the past several decades and atomic energy can then be discussed. And finally, it will be possible to analyze the Atomic Energy Act of 1954 as an expression of federal power policy in its bearing on public and private power.

\section{II}

Power supply in the United States is organized on the following lines: ${ }^{1}$

About sixty-five per cent of the country's electric service is furnished by private utility systems. Ordinarily, each private operating company enjoys a monopoly in a defined territory, and usually, each private utility maintains plants to generate power, transmission systems to carry it to centers of urban or rural use, and distribution systems to make delivery to ultimate consumers in the company's service area. Monopoly in given service areas and integration of large-scale generation with transmission and distribution represent the most economical means of providing electric service, whether supply is public or private.

Nearly twenty per cent of the country's electric service is furnished by federal and local publicly owned systems and cooperatives. (While cooperatives are owned by their member-consumers and regard themselves as private agencies, the utilities

* A.B. I929, University of Pennsylvania; LL.B. 1932, Harvard University. Member of the District of Columbia, New York, and Tennessee bars. Formerly General Counsel, Atomic Energy Commission; Ass't General Counsel, Tennessee Valley Authority; General Counsel, Bonneville Power Administration; Ass't General Counsel, War Production Board; Special Assistant to the Undersecretary of the Department of State. Author [with George F. Trowbridge], Framework for Atomic Industry-A Commentary on THE ATOMc ENergy ACT of I954 (I955). Contributor to legal and other periodicals.

${ }^{1}$ Except as otherwise noted, all of the statistical data about power supply, past and present, are derived from Edison Electric Institute Statistical Bulletin For the YeAr 1954, Electric Utility InDUSTRX IN THE UNITED States (1955). Data about power supply can be expressed in a variety of terms, such as power capacity, energy output, etc. The percentages used in this paper to describe the relative positions of public and private power are based upon capacity figures. Somewhat different percentages would be obtained if energy output were employed; but the trends indicatcd would not be materially different. 
consider them a part of the public-ownership group). The form of organization among these public systems is much less uniform than among the private companies. For example, in the Tennessee Valley region, the TVA generates power which it transmits and sells to large industries and wholesales to municipally owned distribution systems or cooperatives for sale at retail to ultimate consumers. In $\mathrm{Ne}$ braska, where there are no longer any private utilities, a group of state agencies generates, transmits, and distributes power to all consumers in the state. In the Northwest, the Bonneville Power Administration of the Department of the Interior, as marketing agency for Bonneville, Grand Coulee, and other federal hydro-electric projects, is the largest single source of power at wholesale, transmitting and selling it to private utilities, to large industries, to municipal and other publicly owned systems, and to rural cooperatives. Other agencies of the Department of the Interior perform functions similar to the Bonneville Power Administration (but on a lesser scale) in the Southeast, the Southwest, and the Far West. And scattered through the country are still other public and cooperative systems, ranging in size from the large urban systems of the city of Los Angeles and the important REA generation, transmission, and distribution cooperatives to the many small municipal systems and rural cooperatives which exist as islands in the midst of territory served by large private utilities and which frequently depend upon such utilities for their source of wholesale power.

The remainder of the power supply of the country is accounted for by industrial companies, mines, railroads, and street railways which generate for their own use. This segment of the total supply (called self-generation) is not important in relation to the public-versus-private-power controversy. For economic reasons, the proportion of power requirements supplied in this way has been slowly declining for many years.

In contrast, since I932, public power systems and cooperatives have increasingly supplied a greater portion of the market for electric service. In I932, and for a number of prior years, public power accounted for only four to five per cent, as compared with today's twenty per cent; private utilities accounted for seventy-five per cent, as compared with today's sixty-five per cent; and self-generation accounted for twenty per cent, as compared with today's fifteen per cent. ${ }^{2}$ In fact, apart from the absolute increase in the use of electricity, this great comparative growth of public and cooperative systems is the most striking feature of the period.

Many factors have contributed to this phenomenon, but one in particular stands out. Between I932 and about I945, federal power policy constantly encouraged the public-power movement by making newly available to it hydro-electricity. Federal hydro-electricity now comprises nearly half of all the publicly owned supply-or nearly ten per cent of the total electric supply, as compared with less than one per cent in I932. The TVA and the power agencies of the Department of the Interior

\footnotetext{
${ }^{2}$ All of these data are, of course, relative. The over-all power capacity in the United States has approximately quadrupled since 1932, and the present positions of public and private systems represent their respective shares in a greatly enlarged market.
} 
all had their inception in hydro-electric projects, and except for the TVA, all of them still maintain their hydro-electric character. Even the important state enterprises, like those in Nebraska, received their initial impetus through PWA loans and grants to construct locally owned hydro-electric dams. ${ }^{3}$

The marked trend to public power which began in the 30's with the New Deal had, however, slowed down by the close of World War II. Since 1945, for example, there has been no significant territorial expansion by TVA $^{4}$ and few major territorial expansions by other public agencies. ${ }^{5}$ It may be an oversimplification to suggest that the relative stability between public and private power in sharing the total market since the close of the war is the result of a change in political climate. But since the end of the war, Congress has been less willing to authorize entirely new federal hydro-electric projects, one of the prime forces in the public-power movement in the 30's and early $40^{\prime}$ 's. This was true even while President Truman was in office and before the outright opposition of the present administration to expansion of new federal power developments. ${ }^{6}$ And although public power's share of the market rose from about seventeen pe: cent in $195^{\circ}$ to nearly twenty per cent in I954, most of this increase is explained by the immense amounts of power which, with the beginning of the Korean war, the TVA supplied to defense loads, especially in the Atomic Energy Commission installations in Tennessee and Kentucky.

\section{III}

The Roosevelt-Truman administrations favored public development of water resources; but that policy, in itself, is not enough to account for the present strength

\footnotetext{
${ }^{3}$ For a general account of the Nebraska experience, see Clarence A. Davis, Nebraska's Public Power
} Explained (1949); King, Nebraska, the Public Power State, 39 Pun. Uril. Font. 357 (1947). For a history of federal power developments, first as seen in the Truman administration and later as secn in the current administration, see I President's Water Resources Policy Comimission, A Waten Policy for the American People 219 el seq. (i950); 2 Commission on Organization of tile Executive Branch of the Government [Hoover Comm'n], Water Resources and Power 277 et seq. (1955).

See TVA ANn Rep. 2 (1955).

"Final acquisition of private utilities by the public systems in Nebraska was concluded in 1947. Sce note 3 supra. And in 1947 , the Sacramento Municipal Utility District acquired the Pacific Gas and Electric Company system in the Sacramento area. Sec Sacramento Municipal. Utility District Ans. REP. 3 (r954). The only subsequent acquisition of major significance, however, has been the City of Seattle's purchase in I95I of a competing private system in that city. Sec City of Seattre Departarent of Lighting ANN. Rep. I4 (I954).

${ }^{B}$ See, e.g., Congress Rejects Most New Power Projects, Public Power (official publication of the American Public Power Ass'n), Aug. 1952, p. Ir; Power Facilities Slashed, Rural Electrification Magazine, Aug. 1952, p. 23. Congressional inaction paved the way for private development of the Roanoke Rapids hydro-electric site under a license from the FPC and over the strenuous objection of President Truman's Secretary of the Interior. See United States ex rel. Chapman v. FPC, 345 U.S. 153 (1953). The present administration has voiced no opposition to the issuance of an FPC license for the private development of the Hell's Canyon project. See In the Matters of Idaho Power Co., FPC Opinion No. 283 (Aug. 4, x955). Of course, existing federal systems have continued to expand capacity to supply the increasing demands in their existing service areas. And since 1948, REA loans to cooperatives to establish their own generating and transmission systems have been greatly speeded up. See e.g., REA ANn. REP. 13 (1948); id. at 5 (1950). The result of these REA loans, however, has been less to invade private utility service areas than to supplant purchase from utilities at wholesale with power generated by the cooperatives themselves. See, e.g., Kansas City Power \& Light Co. v. McKay, 225 F.2d 924 (D.C. Cir. 1955).

TSe TVA Ann. Rep. 3 (x955). 
and size of public power systems. The huge Boulder project of the Hoover administration was also a federal development of water resources. There, the Government built the Hoover dam but arranged with existing local public and private agencies to divide the water power between them and deliver it with their own transmission systems to their respective market centers. The policies followed with the Hoover Dam, accordingly, did not significantly alter the territorial balance between public and private groups. ${ }^{8}$

The Roosevelt-Truman administrations followed different policies, however. Federal agencies were used both to build dams and market the power from them. Legislation for hydro-electric development was almost always accompanied by a requirement that in the sale of power, preference must be accorded to local publicly owned systems and cooperatives. ${ }^{8}$ In order to make the preference effective, the legislation sometimes authorized construction of federal transmission lines to bring the power to the local markets. ${ }^{10}$ In order to meet the claim of private utilities that such transmission lines resulted in wasteful duplication of facilities, the idea of "wheeling" was conceived. Under this concept, the federal government refrained from building transmission lines, provided the utilities used their own transmission systems to deliver federal power to preference customers for the account of the Government and at a reasonable carrying charge. ${ }^{11}$ This combination of federal policies assured many existing public systems of a new source of power and relieved them of dependence on uneconomic generating plants of their own or dependence on purchases from private companies, which were frequently hostile to the municipal distribution systems to which they sold power at wholesale. Most important, however, is the fact that this federal supply was cheaper than alternative private sources.

It is not within the scope of this paper to deal with the controversy over whether federal hydro-electricity was cheap because it was subsidized by appropriations, tax immunity, and the like; whether it was cheap because it was intrinsically low-cost, efficiently produced water power; or whether the private companies maintained excessively high rates or have received offsetting advantages through the rapid

${ }^{8}$ See I Commsston on Organization of the Executive Branch of the Government [Hoover Comm's], op. cit. supra note 3 , at 94-95 (1955).

${ }^{\circ}$ See, e.g., 48 STAT. 64 (I933), as amended, 49 Stat. I076 (1935), 16 U.S.C. \$83Ii (I946); 50 Stat. 733 (1937), as amended, 54 STAT. 47 (1940), I6 U.S.C. $\$ 832$ (a) (I946); 52 STAT. 405 (I938), I6 U.S.C. $\$ 833 \mathrm{c}(1946) ; 58$ STAT. 890 (1944), as amended, 6r STAT. 50I (1947), I6 U.S.C. \$825s (Supp. 1952). Precedent for these recent statutory preferences is supposed to reside in the Reclamation Act of 1906, 34 STAT. II7, 36 STAT. 930 (I911), 43 U.S.C. $\$ 522$ (I946). Whether this early preference clause had the same purpose as the more recent statutes is now disputed. Compare the testimony of Clarence A. Davis, Hearings before the Subcommittee of the Senate Committee on the Judiciary on Power Policy, 83d Cong., 2d Sess., pt. 2, at 490 (1954), with Lepawsky, Why Public Power Is Here to Stay, The Reporter, Oct. 6, 1955, p. 33 .

${ }^{10}$ Sec, e.g., Tennessee Valley Authority Act of 1933, 48 Stat. 60, as amended, 49 Stat. I075, I080 (1935), 55 STAT. 599 (194I), I6 U.S.C. $\$ 83$ Ic(i), (j) (1946); as to the Bonneville project, see 50 Stat. 732 (I937), as amended, 59 STAT. 546,547 (I945), I6 U.S.C. \$ $832 a$ (b) (I946).

${ }_{11}$ As exemplifying the congressional attitude on wheeling, see S. REP. No. I803, 82d Cong., $2 d$ Sess. 2 (1952). 
amortization privilege. What matters in the result is that municipalities and other public organizations were encouraged by the low cost of federal power and by complementary federal policies to enter the power business on their own account, and numerous new municipal and other public and cooperative systems were organized.

In the early days of the New Deal, these new public and cooperative organizations were also offered the advantage of low-cost financing through PWA loans and grants and through REA low-cost loans. Some of the new agencies, as in the case of the rural cooperatives, began to serve farm areas which had been neglected by private companies. Municipalities, as in the TVA area, planned distribution systems of their own, and by thus threatening to compete with private companies in the same areas, made it necessary for the latter to sell out their systems to the municipalities. ${ }^{12}$

In tracing the recent strength of public power to federal policy, it would be a mistake to minimize the part which purely local agencies have played and will continue to play in the public-power movement. Los Angeles, Seattle, Tacoma, and numerous other municipalities had publicly owned power systems long before the New Deal..$^{13}$ In the early days of the century, municipally owned systems accounted for much more than five per cent of total supply, which was their share in the years just prior to I932. ${ }^{14}$ The New York State Power Authority's recent entrance into the Niagara-St. Lawrence development may stimulate future expansions of public power in the Northeast comparable to those encouraged elsewhere by federal activity during the $30^{\prime}$ 's and the $40^{\circ}{ }^{15}{ }^{15}$ Rural electric cooperatives, which now serve more than half of the farms in the country, would be an important force even if REA ceased to exist.

It is also a mistake to dismiss public power as the invention of radical or Democratic theorists and politicians. Nebraska, an overwhelmingly Republican state, and now entirely served by public power, had thirty-five to forty municipally owned power systems prior to $1932 .{ }^{16}$ And it was the late Senator Robert Taft who, in response to complaints that the REA and the cooperatives were socialistic institutions, is reported to have said that rural electric cooperatives are as American as the Fourth of July.

Finally, it is a mistake to assume that federal power policy and local public ownership always go hand-in-hand. Conflicts occur between different public-ownership groups. ${ }^{17}$ But when national legislation raises issues of public versus private

\footnotetext{
12 The story of these activities is told in the unsuccessful litigation of the utilities to block federal loans and federal power projects. See, e.g. Alabama Power Co. v. Ickes, 302 U.S. 464 (1938); Tennessec Electric Power Co. v. TVA, 306 U. S. Ir8 (I939).

${ }^{13}$ See the testimony of Leland Olds, Hearings before the Joint Committee on Atomic Energy on Development, Growth, and State of the Atomic Energy Industry, 84th Cong., Ist Sess., pt. 3, at 513, 516 (1955).

${ }^{14}$ See Lepawsky, supra note 9 , at 36.

${ }^{15} \mathrm{Cf}$. the testimony of Leland Olds, in Hearings before a Subcommittee of the Senate Committee on Public Works on the Niagara River Power Project, 84th Cong., Ist Sess. 49-69 (1955).

${ }^{10}$ See Davis op. cit. supra note 3, at 14 .

${ }^{17}$ See Davis, $A$ New Look at Federal Power Policy, 53 Pub. Unt. Forr. 135 (1954).
} 
power, the public agencies tend to stand together. This was the case in the debate on the Atomic Energy Act of 1954. The debate was concerned with precedents in federal power law and policy and the theories associated with them. Generally speaking, the public agencies found their supporters among the Democrats rather than among the Republicans.

\section{IV}

A plausible case can be made for applying to atomic energy the rationale of the policies established in the Roosevelt-Truman administrations for developing and marketing water power. The genesis of the federal interest in hydro-electric projects is the commerce, government property, and war powers clauses of the Constitution. ${ }^{18}$ The legal theory most often employed relates to the right of the Government in navigable streams under the commerce clause. In thus exercising its right to improve navigation by construction of dams, the Government is held to realize a proprietary interest in the falling water at the dams. And generation of power therefrom by federal agencies and delivering it to market by transmission lines are regarded as an exercise of rights under the government property clause, ${ }^{19}$ as is accordance of a preference to public agencies and cooperatives in disposing of the power at wholesale.

In their application, these concepts allow ample room to accommodate other purposes. Thus, a federal dam may be built on a stream once navigable, even though improvement of navigation is no longer as important as production of power. ${ }^{20}$ And creation of federally owned hydro-electric power and its delivery and sale to preference customers as a yardstick to supplement regulation of private utility monopolies has been justified for political, social, and economic reasons, apart from orthodox constitutional doctrines. ${ }^{21}$ Development of water power by public rather than private agencies has further been pressed on the theory that water is a natural resource in which all the people have an interest, and their interest can best be realized by giving preference to public authorities in exploiting hydro-electric sites. ${ }^{22}$ The logic of the yardstick idea can be applied as well to steam plants, and the natural resources theory can be applied as well to coal, oil, and gas, the other sources of energy. But historically, the conventional fuels have been exploited by private agencies, and the constitutional bases for federal development of water resources is absent in the case of these fuels.

The analogy between nuclear energy and water power, on the other hand, suggests itself because the atomic enterprise began as a federal monopoly. The wartime work, conducted as a defense measure exclusively under government auspices, was continued under the McMahon Act without significant change, except to replace

\footnotetext{
${ }^{18}$ See 3 President's Water Resources Policy Commission, Water Resources Law 6 (1950).

20 Ashwander v. TVA, 297 U.S. 288 (1936).

${ }^{20}$ Arizona v. California, 283 U.S. 423 (I93I).

${ }^{31} \mathrm{Sec}$, e.g., Hearings before the Joint Committee on Atomic Energy on S. 3323 and H.R. 8862, 83d Cong., 2d Sess., pt. I, at 530 (1954).

${ }^{22}$ See id. at 354 .
} 
army direction with a civilian agency. ${ }^{23}$ As enacted in 1946 , the first atomic energy law seemed likely to reinforce the analogy between atomic power and water power. There is no evidence that this was deliberate on the part of Congress; in fact, it was with reluctance that the Congress adopted the law which continued the public monopoly that had grown up during the war. ${ }^{24}$ In the interests of safety and security, however, private production and ownership of fissionable materials as well as private ownership and operation of nuclear reactors was forbidden. And, by reason of its title to all fissionable materials, the Government had, and still has, a proprietary interest in nuclear fuel which can be likened to its proprietary interest in the falling water of navigable streams. Moreover, by reason of the enormous financial investment of the Government in atomic energy, it has been possible to argue that nuclear energy should be considered a resource which belongs to all the people and which, like water power, should be publicly developed, or very strictly regulated.

At the time the McMahon Act was being debated, arguments of this kind were heard, but they then had no practical significance. The framers of the 1946 law were able to put to one side the always stormy power issue. Economically competitive atomic power was then many years off, and Congress concentrated on diffcult international and domestic questions which had to be met immediately, without forcing other issues which could be deferred.

In I954, despite considerable research and development work by the AEC on power reactors, economical atomic power was still only a prospect. But, by that time, the technology had advanced to the point where economical nuclear power was much more plainly in view than it had been in 1946 . Not only the utilities, but many other industrial concerns expressed an enthusiastic interest in participating in atomic work, provided the law were altered to permit them to work under genuinely private auspices rather than as hired hands of the Government. In agitating for a change in the law, private utilities and other industrial groups sought the right to own nuclear power plants, to own or lease fissionable materials from the Government, and to patent inventions. They realized that safety and security required that the Government should at least regulate private activities, and they offered no objection to the idea that ownership of nuclear reactors and use of fissionable materials should be permitted only under license by the Government. ${ }^{25}$

Discussion of power issues comprised a large part of the congressional hearings and debate on the r954 act. At first, public-power groups suggested that any legislation to weaken the federal monopoly was premature. . This theme runs through the testimony of representatives of such groups and is reflected in the separate report of Congressmen Holifield and Price, members of the Joint Committee on Atomic Energy. Advocates of public power may have hoped that by preserving the federal

${ }^{23}$ See the Atomic Energy Act of 1946, 60 STAT. 755, 42 U.S.C. $\$$ I801-19 (1946).

2s See James R. Newman and Byron S. Miller, The Control of Atomic Energy 3-4 (1948).

${ }^{25}$ See the testimony of representatives of utilities and of other industries, Hearings before the loint Committee on Atomic Energy on Atomic Power Development and Private Eenterprise, 83d Cong., Ist Sess. (1953); Hearings, supra note $2 \mathrm{r}$, pt. r. 
monopoly, atomic energy might one day come to play the same role in strengthening and extending public ownership as federal hydro-electric projects had played in the past. Whether or not this hope was entertained, these groups argued that the technology was not yet sufficiently developed and the political, economic, and social issues had not been sufficiently explored to warrant legislation opening atomic work to private concerns. At the same time, they urged vigorous federal research and development to improve the technology of atomic power production, pointing out that atomic energy was a national resource not to be "given away." 6

Private groups, however, were able to exert much more influence in the legislative struggle. Atomic power study groups composed of private utilities and industrial concerns were instituted in I95I and aggressively pursued the subject thereafter. ${ }^{27}$ In this way, they managed to learn enough about nuclear technology to speak with confidence about the need for legislation and the form it should take. Whether through lack of enterprise or lack of funds on the part of public groups or lack of sympathetic reception of them by the AEC, public power agencies, up to the latter part of 1953 , had not taken part in these studies. ${ }^{28}$ The private groups which had first seized and pressed opportunities to learn about the new field were, thus, in a more advantageous position.

By I954, moreover, most of the reasons which in 1946 impelled the Congress to legislate a federal monopoly had significantly altered. ${ }^{29}$ A powerful tide of opinion favored opening up atomic energy to private development. The Atomic Energy Act of 1954 was the natural result. ${ }^{30}$

\section{V}

As soon as the ineffectual effort to defer any legislation to open up atomic work to industry was swept aside, one issue of profound consequence in the controversy over public versus private power was quickly settled. In July r954, the Joint Committee on Atomic Energy agreed unanimously on a bill to permit private ownership of reactors and private use of fissionable materials. ${ }^{31}$ By this action, private ownership of atomic power plants became possible, and an exclusive or predominantly public development of nuclear plants became improbable. The action of the Congress on other matters, however, did create conditions under which public and private power are enabled to maintain the same relative positions which they held prior to the I954 act in the field of conventional power. ${ }^{32}$ Whether, in the long run,

${ }^{20}$ See the testimony of representatives of public power systems and rural electric cooperatives, Hearings, supra note 25. See also Separate Views of Representative Holifield and Representative Price on H.R. 9757, H.R. Rep. No. 218r, 83 d Cong., 2d Sess. I06 (1954).

${ }^{37}$ See AEC Seventeenth Semiannual Rep. 26 (1955).

${ }^{28}$ See AEC Fifteenth Semiannual Rep. 20 (I954).

${ }^{20}$ See Herbert S. Marks and George F. Trowbridge, Framework for Atomic Industry I-2 (I955).

${ }^{30} 68$ STAT. 92I, 42 U.S.C.A. $\$ \$ 2011-28$ I (Supp. 1954).

${ }^{31}$ See H.R. REP. No. $218 \mathrm{x}$, supra note 26 , at 5-6, 8-9.

${ }^{32}$ An cxtreme view has been expressed about the patent and power provisions of the Atomic Energy Act of 1954 by Adams, Atomic Energy: The Congressional Abandonment of Competition, 55 Colum. L. REv. 158, I79 (1955). He calls the law "unwise, man-made, discriminatory . . legislation which throttles competition and restricts opportunity." Obviously, the writer of this paper disagrees with 
this will be the result depends, of course, on how the law is administered and on what further action Congress takes on the subject.

In summary, the main provisions of the Atomic Energy Act of 1954 relating to power policy are these:

I. Private agencies, public agencies, and cooperatives are all qualified under the I954 act to own and operate power reactors and to obtain nuclear fuel for them. In order to operate reactors and get fuel, however, they must first be licensed by the AEC. ${ }^{33}$ Under the McMahon Act, no agency, public or private (with the exception of the Commission itself), could own and operate a power reactor. ${ }^{84}$

2. Private and public agencies and cooperatives have an equal opportunity under the law to obtain noncommercial licenses for experimental power reactors. ${ }^{35}$ The policy of the law is to give strong encouragement to all comers to engage in the research and development work necessary to advance the technology to a point where atomic power can compete with conventional sources of power. ${ }^{38}$

3. In granting commercial licenses for power reactors (presumably plants which are economically competitive with conventional power plants), the law stipulates that preference shall be given to public agencies and cooperatives as well as to high-cost power areas. ${ }^{37}$ As to the preference to public agencies and cooperatives, this feature of the law appears to favor public power.

4. The AEC may itself build experimental power reactors and sell the power they produce. ${ }^{38}$ It may also build reactors to make fissionable material, it may design them so that they will generate power as a by-product, and it may sell the by-

Professor Adams. On patent questions, which are not dealt with in this paper, Professor Adams' appraisal should be contrasted with that of Casper W. Ooms. See Ooms, Revision of the Patent Provisions -Good or Bad?, in Minutes of the Third Annual Conference, Atomic Enency in Industry, National Industrial Conference Board, New York City, October 13-14, 1954, 279 (I954); and Is the New Atomic Energy Act a Patent Give-away?, a paper delivered at Conference on Atomic Energy for Industry, Atlanta, Ga., Oct. 28, x954. In the same vein, see also Boskey, Patents Under the Netv Alomic Energy Act, 36 J. PAT. OfF. Soc'Y 867 (1954).

${ }^{33}$ See $\$ \$ 53$, 103, 104, 68 STAT. 930, 936, 937, 42 U.S.C.A. $\$ \$ 2073,2133,2134$ (Supp. r954).

${ }^{34}$ See $\$ \$ 4(\mathrm{~b}), 4(\mathrm{c})(\mathrm{r}), 7(\mathrm{a}), 5(\mathrm{a})(2), 5(\mathrm{a})(3), 5(\mathrm{a})(4), 60$ STAT. 759, 764, 760 (1946), 42 U.S.C. $\$ \$ 1804(b),(c)(I), I 807(a), 1806(a)(2)-(4)$ (1946). In the debate on the 1954 act, there was an unsuccessful effort to make commercial licensees of atomic plants subject to all the conditions of licensecs under the Federal Power Act. See Separate Vieus of Representative Holifield and Representative Price, H.R. REP. No. 2181, supra note 26, at $120-22$. Instead, the law simply makes interstate sales of nuclear energy subject to the usual regulation of such sales by the FPC. 68 STAr. 960, 42 U.S.C.A. \$2019 (Supp. 1954). However, even had the separate views of Representatives Holifield and Price prevailed, it probably would not have deterred private companies from seeking licenses. They prefer to avoid the restrictions of the Federal Power Act. See United States v. Appalachian Electric Power Co., 3 II U.S. 377 (1940). But they are no longer discouraged thereby from undertaking hydro-electric projects. See cases cited supra note 6.

${ }^{35}$ See $\$ 104,68$ STat. 937, 42 U.S.C.A. \$2r34 (Supp. 1954). It is possible to argue that public and cooperative agencies are entitled to treatment in the nature of a preference in connection with licenses for experimental power reactors. See Marks and Trowbrudge, op. cit. supra note 29, at 40-41. However, the Commission has construed the law (and this is probably in keeping with the intention of the Congress) as treating all applicants for noncommercial licenses alike. Sce AEC Notice of Proposed Rule Making, 20 FED. Reg. 2486 (1955); and Note, id. at 2489.

${ }^{30}$ Cf. H.R. REP. No. 2181, supra note 26 , at 9.

${ }^{37}$ See $\$ 182(c)$, 68 STAT. 954, 42 U.S.C.A. $\$ 2232$ (c) (Supp. r954).

${ }^{38}$ See $\$ 31($ a) (4), 68 STAT. 927, 42 U.S.C.A. $\$ 205$ I(a)(4) (Supp. 1954). 
product $^{39}$ But the law prohibits the AEC from building atomic power plants for the sale of power commercially if such plants are unrelated to research or to production of fissionable material. ${ }^{40}$

5. In selling power from its own experimental reactors or as a by-product of its production reactors, the law stipulates that the AEC must give preference to public agencies, cooperatives, and high-cost power areas. ${ }^{41}$

The discussion of the law which follows is concerned chiefly with the preference features of the law.

The preference in favor of public agencies and cooperatives in granting commercial licenses is analogous to the preference which the Federal Power Act gives to public applicants for licenses to build hydro-electric projects. ${ }^{42}$ It is difficult to foresee whether this preference in the Atomic Energy Act of 1954 will be more significant than its analogue. Nature has created only a limited number of desirable hydro-electric sites, and the FPC has construed its law to mean that, other things being equal, competition for a license between a public and a private agency will be resolved in favor of the former. ${ }^{43}$ In the case of atomic power, however, the number of plants is limited only by the markets for power and the availability of nuclear fuel. The economics of the utility business has usually dictated that any given market should be served by a single electric system, public or private. As far as markets are concerned, therefore, a preference in granting commercial licenses to public agencies and cooperatives is not likely to be important unless public power seeks to invade an area already served by a private utility. But even if public groups attempt to take advantage of the preference in this way, their efforts may be neutralized if there is enough nuclear fuel available for both a public and a private plant. And all the present indications are that nuclear fuel will become so plentiful in relation to the probable market that public agencies will not need to invoke their preference right to commercial licenses. For the time being, however, the question is academic, as the technology is not yet sufficiently advanced to permit construction of atomic power plants which require a commercial license.

A number of reactor designs are now being tried out by the AEC in its own experimental program. ${ }^{44}$ Various power companies and manufacturers have welladvanced plans for building experimental reactors under license from the Commission. ${ }^{45}$ These private reactors all qualify for noncommercial licenses, even though some of them will produce from a hundred to two hundred thousand kilowatts, amounts of power comparable to the capacities of modern, conventional steam plants. Local public agencies and cooperatives also have plans for building

${ }^{30}$ See $\$ 44,68$ StaT. 929, 42 U.S.C.A. $\$ 2064$ (Supp. 1954).

${ }^{10} \mathrm{lbid}$.

${ }^{11}$ Ibid.

${ }^{42}$ Cf. 49 Stat. 842 (1935), I6 U.S.C. $\$ 800$ (1946). This provision of the Federal Power Act had its inception in the original Federal Water Power Act of 1920, 4I STAT. 1067.

${ }^{43}$ See Hearings, supra note 15 , at 11 .

"Sec AEC Eightentim Semiannual Rep. 34 (1955).

${ }^{15}$ See id. at $4 \mathrm{~T}-42$. 
experimental power reactors of substantial size under license from the AEC.40 As now presently construed by the AEC, the law gives no preference to public or cooperative bodies that wish to obtain licenses for experimental reactors, but, as will appear at a later point, the Commission has recently shown signs of willingness to grant some financial aid for such reactors. ${ }^{47}$

The preference which the law accords in the sale of power from AEC experimental reactors, or as a by-product of AEC production plants, is presently of doubtful value. Experimental power reactors will be high-cost or unreliable producersotherwise they will be commercial plants, in which case the AEC is prohibited from building them. Public agencies are now fighting for recognition of their preference right to power from the AEC's experimental reactor at West Milton, New York. ${ }^{48}$ In this fight, no substantial economic advantage is at stake. The West Milton plant produces an insignificant amount of dump power which cannot be relied upon to serve ordinary utility loads. It has been priced by the AEC at 3 mills per kilowatt-hour, a figure which bears no relation to its high cost, but is in line with the value of dump power. ${ }^{49}$ Since an atomic kilowatt-hour is physically indistinguishable from a conventional kilowatt-hour, it may be assumed that the private and public utilities which are so eager to buy at wholesale and retail the power from the AEC's small experimental reactors see prestige rather than any economic value in the atomic kilowatt-hours. The public agencies also view the West Milton case as a situation in which they must assert their legal preference in order to establish a precedent in the administration of the law, especially their conception of a federal responsibility to arrange for wheeling in their behalf in order to make their preference effective. ${ }^{50}$ But the AEC is building only one large-scale experimental reactor today-the plant at Shippingport, Pennsylvania, started under the McMahon Act; and at this plant, the high-cost experimental power was disposed of by arrangements with a private utility before the 1954 preference became law. ${ }^{\text {t1 }}$

It may be, however, that in the future the AEC will build other large experimental reactors. ${ }^{52}$ Such reactors may produce sizable amounts of reliable power, and a new AEC with a different political orientation might price the power at a cost sufficiently lower than its real cost to make it attractive as compared with

\footnotetext{
${ }^{\circ}$ See $i d$. at 42; also Bradburn, Minnesota System Proposes Atomic Potver Plant, Rural Electrification Magazine, Aug. 1955, p. I3.

"See note 35 supra.

${ }^{48}$ See remarks of Senator Humphrey, IOI Cong. REc. I0945 (daily ed. Aug. I, 1955); remarks of Representative Evins, id. at A5790 (daily ed. Aug. 3, 1955); Congressman Davidson charges AEC with Giving Private Utility "Inside Track," Press Release by Representative Irwin D. Davidson (N.Y.), Scpt. 9, 1955; speech by Alex Radin, General Manager, American Public Power Ass'n, before the Municipal Electric Utilities Ass'n of New York State, Sept. 9, 1955.

${ }^{10} \mathrm{See}$ AEC Release No. 663, July I3, 1955. Cf. speech by Alex Radin, supra note $4^{8 .}$

${ }^{60}$ See note 48 supra, especially Mr. Radin's speech.

${ }^{11}$ See AEC Release No. 526, March 14, I954.

62 See, e.g. S. 2725, 84th Cong., Ist Sess. (1955). This bill, submitted by Senator Gore, which is pending in committee, would authorize and direct the AEC to build six experimental power reactors, located in different geographical sections of the country, at sites selected with a view, among other things, to the need for electric generating capacity in the region of the sites.
} 
alternative conventional sources. In that event, the preference rights of public and cooperative agencies would be valuable. It should be observed that even under the legislation of the $30^{\prime}$ 's and the $40^{\prime}$ 's, when federal policy strongly favored public and cooperative groups, the statutes prohibited federal agencies from making such baldly below-cost sales. ${ }^{53}$ But the same result might be achieved under the provisions of the Atomic Energy Act of 954 relating to "production" reactors.

The preference to public and cooperative agencies in purchasing by-product power from AEC production reactors could be important if any reactors of this kind were to be built. Britain's atomic power program is being launched with production plants which will make substantial amounts of plutonium for weapons and power as a by-product. In England, the plutonium is assigned an arbitrarily high value. The by-product power can then be priced at a figure which makes it competitive with conventional power. ${ }^{54}$ The AEC has no plants of this kind, and today none are in prospect. There is little support in this country for following the British program. Our policy is to build and operate production plants designed solely to make fissionable materials, while experimenting with a large number of different reactors designed primarily to produce power. But a change in the political mood regarding power and atomic energy could alter this condition. Nearly all large power reactors, whether experimental or commercial, can produce substantial quantities of nuclear fuel as well as power. If the AEC should launch a new program of its own to build large reactors, it could treat them as production reactors, while designing them also to make substantial quantities of power, classified as a by-product. As in the case of the British program, the by-product power could be priced at a competitive figure. If such action were coupled with a federal policy of encouraging new public agencies, as in the 30's and the 40's, the result might be a resumption of the trend of public agencies to increase their relative share in the total power market. All of this is, of course, highly conjectural and, in any case, not likely to occur under the present administration.

Once the stage of experimentation is past and economically competitive power plants become feasible, the AEC is forbidden to build them. This prohibition was written into the law by members of Congress who wished to keep the AEC out of the power business. Supporters of public power had urged that instead of forbidding such activity by the AEC, the law should affirmatively authorize it to build commercial plants or commission other federal agencies to do so. They urged that marketing of the power be the responsibility of the Department of the Interior, pursuant to the Flood Control Act of I944, which gives preference to public agencies and cooperatives. The so-called Johnson amendment was adopted by the Senate for this purpose, but it was killed in conference. ${ }^{55}$ Had the Senate amendment become law,

${ }^{63}$ See, e.g., the famous $\S 5$ of the Flood Control Act of 1944,58 STAT. $890, x 6$ U.S.C. $\$ 825$ s (1946).

${ }^{53}$ See the White Paper, A Programme of Nuclear Power, CMd. No. 9389, at 4-5 (1955).

${ }^{56}$ See H.R. 9757, To Amend the Atomic Energy Act of 1946, 83d Cong., 2d Sess. $\$ 45$ (1954), as passed by the Senate, July 27, 1954; see also H.R. REp. No. 2639, 83 d Cong., 2d Sess. 45-46 (1954), and H.R. Rep. No. 2666, 83 d Cong., 2d Sess. 47-48 (1954). 
an administration pledged to the federal power policy of the Roosevelt-Truman administrations might have tried to invoke the authority to establish commercial plants to repeat, with atomic power, the process of extending public ownership which occurred with hydro-electric projects.

But the failure of the Johnson amendment and the prohibition on construction of commercial plants by the AEC or its federal nominees are not necessarily of great practical consequence. When commercial plants become feasible, the AEC or other federal agencies will be able to obtain enabling legislation and appropriations to build such plants, provided political conditions favor developments of that kind. On the other hand, even had the Johnson amendment been adopted, neither the AEC nor other federal power agencies could have invoked it without obtaining appropriations from Congress; and in most instances, a further congressional enabling act, in addition to the Johnson amendment, would have been necessary before a federal agency could have sought an appropriation for a commercial reactor. ${ }^{\text {bo }}$

In addition to the provisions of the law which deal explicitly with power policy, there are others which are relevant to the subject. The Commission is required to fix a "fair" price for fissionable materials produced in the reactors of others, and is also authorized to furnish a variety of services and materials in aid of the reactor projects of others and to fix the price for them. The provisions of the law also permit the AEC to give services and to loan materials without charge in aid of experimental reactors, whether publicly or privately owned, as well as to give certain direct financial assistance to public and private agencies in carrying out research and development work associated with experimental reactors. And in the case of commercial reactors, whether public or private, the law requires the AEC to fix a "reasonable" charge for services and materials which it furnishes. ${ }^{57}$

Because the law is written in general and sometimes ambiguous terms, and because of the secrecy which surrounds the AEC's conduct of its affairs, there are obvious opportunities for hidden subsidies and for arbitrary action in granting subsidies through price-fixing or otherwise. In its actions to date, however, the AEC appears to have adopted policies on price-fixing and financial assistance to reactor projects which avoid hidden subsidies and arbitrary discrimination, either in favor of private reactors or in favor of those proposed by public agencies. ${ }^{68}$

In its initial actions on proposals for power reactors under the new law, the AEC sought to avoid any subsidy. Thus, in its first-round reactor program, the AEC

${ }^{50}$ As illustrative of the parliamentary process, see the following materials on the further enabling legislation necessary to authorize appropriations for new projects under the Atomic Energy Act of r954: Hearings before the Subcommittec on Authorizing Legislation of the Joint Committee on Alomic Energy, 84th Cong., Ist Sess. (I955); H.R. ReP. No. 787, 84th Cong., Ist Sess. (I955); 69 Stat. 291 (I955). See also Marks AND Trowbridge, op. cit. supra note 29, at 69-70. It is doubtful that $\$ 272$ of the Atomic Energy Act of 1954, 68 STAT. 960, 42 U.S.C.A. \$2019 (Supp. 1954), which was adopted as a partial substitute for the Johnson amendment, will assist federal power agencies in short-cutting the normal legislative process.

${ }^{57}$ For general discussion of these provisions, see MARKS AND Trowbridge, op. cit. supra note 29, at 43-59.

${ }^{8}$ See id. at 45,47 . 
approved two proposals of private groups which asked no substantial assistance from the Government, except in the form of insurance. At the same time, it rejected, provisionally, two proposals, one of a private group, the other of the Consumers Public Power District of Nebraska, because each sought substantial government aid. ${ }^{59}$

In the Commission's second-round reactor program, however, a policy of federal aid is clearly contemplated. It (I) invites proposals for small size reactors $(5,000$ kilowatts to 40,000 kilowatts); (2) holds out the prospect of substantial financial assistance to those who propose projects; and (3) expresses willingness to consider financial assistance in the form of AEC construction and ownership of the reactor phase of the project, with ownership of the conventional turbo-generator in a power agency or industrial concern. ${ }^{60}$ On its face, this latter program is designed only to encourage experimental work on perfecting small nuclear power plants, a field where, to date, the technology has lagged behind that of the larger types. But the offer of financial assistance and AEC construction and ownership of the reactors could also operate in favor of public agencies, which are more interested than private utilities in small plants. The public bodies also have a greater need for government assistance because they are not as favorably situated as private companies in finding money for experimental work. Federal agencies must look to Congress for appropriations, and most of the state and municipal systems and the cooperatives are operated on the theory of selling power at cost, without profit, and, accordingly, do not build up reserves which can be used in research and development. Private utilities, on the other hand, are able to use their funds for experimental work and charge the costs to operating expense with a consequent tax deduction. ${ }^{61}$

Even if private companies do not seek help from the AEC in building experimental power plants, the public groups will certainly continue to seek such aid. They can argue that since the law gives them a preference in obtaining commercial licenses, they ought to be helped by the Government in conducting the experimental work which must precede the building of economically competitive plants. In the case of existing public agencies, this argument seems just now to be influencing actions of the AEC. The second-round small reactor program is one sign in this direction. Another is the recent decision of the Commission to reconsider the proposal by the Consumers Public Power District of Nebraska for a large experimental reactor on terms which would involve considerable financial assistance from the AEC. ${ }^{62}$ But actions along these lines will not enable public agencies to invade markets now served by private companies. They will help public groups to begin to acquire experimental atomic power plants and to become experienced in the new technology.

In the analysis of the Atomic Energy Act of r954 and its administration just concluded, it should be apparent that, in the view of this writer, the law favors private

\footnotetext{
${ }^{60}$ See AEC Release No. 674, Aug. 8, I955.

${ }^{\circ 0}$ See AEC Release No. 695, Sept. 21, 1955.

${ }^{01}$ See e.g., Re The Detroit Edison Company (Mich.) Docket No. 1282A-55.x, Mar. 23, I955.

${ }^{02}$ See AEC Release No. 723, Oct. 27, 1955.
} 
power-but primarily in the sense that it opened the field of atomic energy to private development and thereby made improbable an exclusively government development of nuclear energy, with the strengthening and enlargement of the public-power movement that would have resulted from such a course. The preferences won by public groups are, however, a balancing factor, although they are not likely to cause an early return to the trend of the $30^{\prime}$ 's and 40's when public power occupied an increasingly larger proportion of the market. Rather, the net effect of these preferences will be to help public agencies hold their ground. In this respect, the law and its administration reflect the fact that public power groups are sufficiently strong politically to preserve their position, even in an administration that cannot be characterized as friendly to them. ${ }^{63}$

\section{VI}

Nearly everyone now realizes that nuclear power must be regarded as another form of energy which can ultimately take its place with coal, oil, gas, and falling water as a means of generating electric power. Atomic power, sooner or later, will become competitive with power produced from other sources of energy. At that time, it will supplement them. It is not likely soon to displace them.

Present use of power is expected nearly to double by 1965 and double again in the following decade. If these forecasts are realized, the United States will have on the order of 200,000,000 kilowatts of electric capacity in 1965 and 400,000,000 kilowatts in 1975 . Predictions about the proportion of the new installations that will be atomic plants vary so widely, however, that they merely emphasize the uncertainty that surrounds the subject. One careful study concludes that the best guess that can be made as to the amount of atomic power likely to be in use in the United States by I965 is a range somewhere between one and thirteen million kilowatts. ${ }^{64}$ Looking still further ahead, the Director of the AEC's Reactor Development Division thinks it possible that by 1975 to I980 the total amount of nuclear power in use in the United States may be as much as I0o million kilowatts. ${ }^{65}$

Meanwhile, the gradual evolution of the technology which is expected some day to make atomic energy competitive with conventional sources is taking place in a context of law and administrative policy which reflects the attitude of the present administration on the general subject of federal power policy. The administration has been careful to limit its explicit disapproval of public power to expansion of

${ }^{e s}$ Cf. notes 60 and $6 \mathrm{r}$ supra. Also cf. Opinion of the Attorney General, concerning the proposal with the Georgia Power Company for the marketing of electric energy generated at the Clark Hill Reservoir Project, July 15, I955; speech by AEC Chairman Strauss, The Promises and Problems of Nuclear Power, at Case Institute of Technology, AEC Release, Nov. 9, 1955; separate statements of Messrs. Brownell and Fleming, 2 Commission on Organization of the Executive Branch op tue Governament [Hoover Comm'N], op. cit. stipra note 3 , at 3 .

${ }^{\circ}$ See Atomic Industrial Forum, A Growth SuRvey of the Atomic Industry 1955-65, at 36 (1955). The forecasts in this survey are stated in terms of kilowatts of heat capacity. These terms can be translated into kilowatts of electric capacity by dividing by four.

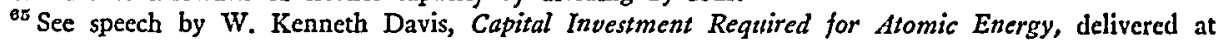
the International Conference on the Peaceful Uses of Atomic Energy, Geneva, Switzerland, Aug. 9, $x 955$. 
federal activities. Its avowed policy is one of local option as between public and private agencies. Existing private systems are beginning work on experimental nuclear plants. Existing public systems will probably soon be building theirs. Manufacturers of power equipment are offering power reactors for sale to public and private systems in the same way that the manufacturers now supply the needs of public and private systems with conventional equipment. Accordingly, under today's law and policy, there is no indication that the relative position of the public and private systems will be altered by the emergence of atomic power. But power is always an explosive political issue. No one who is familiar with the history of the ups and downs of public and private power during the past half century is likely to predict that present law and policy represent the last word on the subject. 